\title{
Plutonium Fallout in Tokyo
}

\author{
by \\ Yasuo Miyake \\ Geochemistry Research Association, Tokyo \\ Yukio Katsuragi and Yukio Sugimura \\ Meteorological Research Institute, Tokyo
}

(Received December 20, 1974)

\begin{abstract}
The monthly fall rates of plutonium 239 and 238 in Tokyo during the period from Jan. 1967 to the end of 1973 are given. The cumulative amounts of plutonium fallout in Tokyo from the beginning of nuclear explosion to the end of 1973 are estimated to be $1.2 \mathrm{mCi} / \mathrm{km}^{2}$ and $55 \mu \mathrm{Ci} / \mathrm{km}^{2}$ respectively for 239 and 238 . Owing to the accidental release of 238 due to a satellite failure, ratio of 238 to 239 increased abruptly in 1967 from $1.8 \%$ in 1966 to $16 \%$ in 1967 . The maximum value of the ratio, $31 \%$, was observed in 1970 , and then the value decreased gradually to $6.3 \%$ in 1973 . The ratio of 239 to $\mathrm{Sr}-90$ during the period of 1968 to 1973 , in which the Chinese bomb tests prevailed, was about $1 \%$, which was lower than the former value of $1.6 \%$ in the tests conducted by the USA and the USSR. The total amounts of deposition in the northern hemisphere of 239 and 238 were calculated to be about $200 \mathrm{kCi}$ and $9 \mathrm{kCi}$ respectively. In $9 \mathrm{kCi}$ of $238,2 \mathrm{kCi}$ was of satellite origin.
\end{abstract}

\section{Introduction}

It is well known that small amounts of plutonium isotopes with mass numbers 238, 239 and 240 are contained in the radioactive fallout derived from nuclear bomb explosions. Among the above isotopes the amount of 240 is much smaller than that of 239 which has almost the same alpha energy spectra as those of 240 . Therefore, in this paper, the plutonium isotopes in the fallout are represented by two isotopes, i.e. 238 and 239.

In our laboratory, detailed records have been kept since 1958 on the monthly fall rate of the plutonium isotopes in Tokyo. Concerning the monthly depositions of 239 and 238 in Tokyo during the period from March 1958 to April 1969, the reports were presented already (MIYAKE et al., 1968, 1970). According to the previous reports, the cumulative amount of 239 and 238 during the period mentioned above were $0.97 \mathrm{mCi} / \mathrm{km}^{2}$ and $43 \mu \mathrm{Ci} / \mathrm{km}^{2}$ respectively. The average activity ratio of 239 to $\mathrm{Sr}-90$ was $1.6 \%$. On the other hand, average activity ratio of 238 to 239 was $3.9 \%$ until the end of 1966 , which was a little higher than those observed by deBorToLI et al. (1969) and HARDY et al. (1972), i.e. respectively $2 \%$ and $2.4 \%$. The 238 to 239 ratio began to increase 
suddenly in 1967 in Tokyo (see also TELEGadAs et al., 1969), and a maximum of $31 \%$ was reached in 1970 as shown later in Table 2 . This strange relative increase in 238 was due to a mistake by the USA in orbiting the SNAP-9A satellite in the southern hemisphere over the Indian Ocean in the spring of 1964, which was loaded with $17 \mathrm{kCi}$ of 238 as a power source. With respect to the residence time in the stratosphere of 239 , it was estimated to be about 1.7 years, which was a little longer than that of Sr-90 (MIYAKE et al., 1968).

In this paper, the results of further observations of the plutonium fallout carried out in Tokyo during the period from January 1967 to the end of 1973 are reported. Some discussions are presented concerning the inventory of the plutonium isotopes both of bomb- and satellite-origins.

\section{Samples and the method of determination}

The samples of meteoritic precipitations together with falling dusts were collected monthly. A water sample of about 10 to 200 liters was dried up and the residue was digested with $6 \mathrm{M} \mathrm{HCl}$ a few times, and the solution was subjected to analysis. The method of analysis was almost the same as described in the previous paper (MIYAKE et al., 1968). Plutonium in the solution was coprecipitated with a small amount of ferric hydroxide, and was isolated from a larger amount of other substances by means of an anion exchange resin in the nitrate form. The plutonium isotopes were electroplated on a disk cathode made of stainless steel (30 mm dia.) for $90 \mathrm{~min}$. in the ethyl alcohol-HCl media at a voltage of 15 volts and a current of $300 \mathrm{~mA}$ (MIYAKE and SUGImura, 1968). The chemical yield of separation was $60 \pm 10 \%$. Measurement of alpha-ray intensities of 239 and 238 was done with an alpha-ray spectrometer which consists of a solid state detector coupled with a multichannel pulse height analyzer.

\section{Results and discussions}

In Table 1 and Fig. 1, the monthly fall rates of 239 and 238, and the activity ratio of 238 to 239 in Tokyo during the period from January 1967 to the end of 1973 are shown. In Table 1, the amounts of precipitation are also given. In Table 2 and Fig. 2, the annual amounts of fall of 239 and 238 are given. In Table 2, the estimated value of the plutonium fallout from the beginning of nuclear explosions through February 1958 is also given.

The calculation was done by assuming the activity ratios of 239 to Sr-90 and 238 to 239 respectively to be $1.6 \%$ and $3.9 \%$, on the basis of the observed value of Sr-9C deposition until February 1958 (MrYAKE et al., 1963).

As shown in Table 2, the cumulative amounts of plutonium fallout in Tokyo to tue end of 1973 are $1.2 \mathrm{mCi} / \mathrm{km}^{2}$ and $55 \mu \mathrm{Ci} / \mathrm{km}^{2}$ respectively for 239 and 238 . As mentioned above, owing to the accidental release of 238 due to a satellite failure, the ratio of 238 to 239 increased abruptly in 1967-from $1.8 \%$ in 1966 to $16 \%$ in 1967 . The maximum value of the ratio of $31 \%$ was observed in 1970 and then the value decreased gradually to $6.3 \%$ in 1973 .

Since the cessation of surface tests by the US and the USSR in 1963, the annual rate of radioactive fallout in Tokyo decreased rapidly with a half-life of about one year. However, it is to be noted that the fall rate in Tokyo of Sr-90 etc, has not 
Table 1. Monthly deposition of plutonium 239 and 238 and the ratio of 238 to 239 in Tokyo.

\begin{tabular}{|c|c|c|c|c|c|}
\hline \multicolumn{2}{|c|}{ Date } & $\begin{array}{c}239 \\
\mu \mathrm{Ci} / \mathrm{km}^{2}\end{array}$ & $\begin{array}{c}238 \\
\mu \mathrm{Ci} / \mathrm{km}^{2}\end{array}$ & $\begin{array}{c}238 / 239 \\
(\%)\end{array}$ & $\begin{array}{c}\text { Precipitation } \\
\mathrm{mm}\end{array}$ \\
\hline \multirow[t]{12}{*}{1967} & Jan. & $1.4 \pm 0.1$ & $0.10 \pm 0.01$ & 7.7 & 33 \\
\hline & Feb. & $2.7 \pm 0.3$ & $0.14 \pm 0.01$ & 5.4 & 55 \\
\hline & Mar. & $1.9 \pm 0.2$ & $0.43 \pm 0.04$ & 22 & 69 \\
\hline & Apr. & $1.6 \pm 0.2$ & $0.26 \pm 0.03$ & 16 & 111 \\
\hline & May & $3.6 \pm 0.4$ & $1.41 \pm 0.1$ & 40 & 52 \\
\hline & June & $1.0 \pm 0.1$ & $0.27 \pm 0.03$ & 27 & 147 \\
\hline & July & $1.9 \pm 0.2$ & $0.21 \pm 0.02$ & 11 & 130 \\
\hline & Aug. & $0.9 \pm 0.1$ & $0.03 \pm 0.003$ & 3.5 & 140 \\
\hline & Sept. & $1.6 \pm 0.2$ & $0.18 \pm 0.02$ & 12 & 211 \\
\hline & Oct. & $2.3 \pm 0.2$ & $0.02 \pm 0.002$ & 0.8 & 158 \\
\hline & Nov. & $1.4 \pm 0.1$ & $0.20 \pm 0.02$ & 15 & 64 \\
\hline & Dec. & $0.7 \pm 0.1$ & $0.09 \pm 0.01$ & 13 & 28 \\
\hline \multicolumn{2}{|l|}{ Sum. } & 21 & 3.3 & av.* 15.7 & 1,208 \\
\hline \multirow[t]{12}{*}{1968} & Jan. & $1.2 \pm 0.1$ & $0.08 \pm 0.01$ & 7.0 & 9 \\
\hline & Feb. & $0.3 \pm 0.03$ & $0.03 \pm 0.003$ & 9.6 & 72 \\
\hline & Mar. & $2.6 \pm 0.3$ & $0.20 \pm 0.03$ & 7.4 & 77 \\
\hline & Apr. & $4.2 \pm 0.4$ & $0.11 \pm 0.01$ & 2.6 & 131 \\
\hline & May & $2.2 \pm 0.2$ & $0.06 \pm 0.01$ & 2.7 & 174 \\
\hline & June & $4.2 \pm 0.4$ & $0.17 \pm 0.02$ & 4.1 & 203 \\
\hline & July & $3.6 \pm 0.4$ & $0.22 \pm 0.02$ & 6.1 & 177 \\
\hline & Aug. & $1.5 \pm 0.2$ & $0.30 \pm 0.03$ & 20 & 268 \\
\hline & Sept. & $1.9 \pm 0.2$ & $0.46 \pm 0.05$ & 24 & 111 \\
\hline & Oct. & 2. $1 \pm 0.2$ & $0.59 \pm 0.06$ & 27 & 160 \\
\hline & Nov. & $0.5 \pm 0.05$ & $0.13 \pm 0.01$ & 25 & 39 \\
\hline & Dec. & $0.8 \pm 0.1$ & $0.19 \pm 0.02$ & 24 & 215 \\
\hline \multicolumn{2}{|l|}{ Sum. } & 25 & 2.5 & av.* 10 & 1,644 \\
\hline \multirow[t]{12}{*}{1969} & Jan. & $1.2 \pm 0.1$ & $0.15 \pm 0.02$ & 13 & 74 \\
\hline & Feb. & $1.0 \pm 0.1$ & $0.12 \pm 0.01$ & 12 & 114 \\
\hline & Mar. & $1.0 \pm 0.1$ & $0.24 \pm 0.02$ & 24 & 140 \\
\hline & Apr. & $1.0 \pm 0.1$ & $0.15 \pm 0.02$ & 15 & 72 \\
\hline & May & $2.3 \pm 0.2$ & $0.65 \pm 0.07$ & 29 & 104 \\
\hline & June & $0.4 \pm 0.04$ & $0.25 \pm 0.03$ & 58 & 185 \\
\hline & July & $0.5 \pm 0.05$ & $0.23 \pm 0.02$ & 46 & 188 \\
\hline & Aug. & $0.6 \pm 0.06$ & $0.15 \pm 0.02$ & 27 & 120 \\
\hline & Sept. & $1.8 \pm 0.2$ & $0.30 \pm 0.03$ & 17 & 181 \\
\hline & Oct. & $1.4 \pm 0.1$ & $0.33 \pm 0.03$ & 24 & 148 \\
\hline & Nov. & $0.4 \pm 0.04$ & $0.26 \pm 0.03$ & 66 & 110 \\
\hline & Dec. & $0.2 \pm 0.02$ & $0.18 \pm 0.02$ & 89 & 27 \\
\hline \multicolumn{2}{|l|}{ Sum. } & 12 & 3.0 & av.* 25 & 1,471 \\
\hline \multirow[t]{3}{*}{1970} & Jan. & $0.2 \pm 0.02$ & $0.32 \pm 0.03$ & 178 & 74 \\
\hline & Feb. & $0.4 \pm 0.04$ & $0.28 \pm 0.03$ & 77 & 40 \\
\hline & Mar. & $0.4 \pm 0.04$ & $0.34 \pm 0.03$ & 90 & 51 \\
\hline
\end{tabular}


Table 1. (continued)

\begin{tabular}{|c|c|c|c|c|c|}
\hline \multicolumn{2}{|c|}{ Date } & $\begin{array}{c}239 \\
\mu \mathrm{Ci} / \mathrm{km}^{2}\end{array}$ & $\begin{array}{c}238 \\
\mu \mathrm{Ci} / \mathrm{km}^{2}\end{array}$ & $\begin{array}{c}238 / 239 \\
(\%)\end{array}$ & $\begin{array}{l}\text { Precipitation } \\
\mathrm{mm}\end{array}$ \\
\hline \multirow[t]{9}{*}{1970} & Apr. & $0.9 \pm 0.1$ & $0.43 \pm 0.04$ & 46 & 95 \\
\hline & May & $1.0 \pm 0.1$ & $0.10 \pm 0.01$ & 9.7 & 150 \\
\hline & June & $1.4 \pm 0.1$ & $0.20 \pm 0.02$ & 15 & 209 \\
\hline & July & $0.5 \pm 0.05$ & $0.03 \pm 0.003$ & 7.7 & 56 \\
\hline & Aug. & $0.4 \pm 0.04$ & $0.04 \pm 0.004$ & 9.8 & 62 \\
\hline & Sept. & $0.3 \pm 0.03$ & $0.04 \pm 0.004$ & 12 & 84 \\
\hline & Oct. & $0.4 \pm 0.04$ & $0.07 \pm 0.01$ & 17 & 100 \\
\hline & Nov. & $0.2 \pm 0.02$ & $0.02 \pm 0.002$ & 13 & 127 \\
\hline & Dec. & $0.03 \pm 0.003$ & $0.01 \pm 0.001$ & 19 & 28 \\
\hline \multicolumn{2}{|l|}{ Sum. } & 6 & 1.9 & av.* 31.7 & 1,082 \\
\hline \multirow[t]{12}{*}{1971} & Jan. & $0.01 \pm 0.001$ & $0.001 \pm 0.0005$ & 9.1 & 61 \\
\hline & Feb. & $0.3 \pm 0.03$ & $0.02 \pm 0.002$ & 4.7 & 46 \\
\hline & Mar. & $0.8 \pm 0.08$ & $0.05 \pm 0.005$ & 6.6 & 79 \\
\hline & Apr. & $1.0 \pm 0.1$ & $0.12 \pm 0.01$ & 12 & 111 \\
\hline & May & $1.1 \pm 0.1$ & $0.08 \pm 0.01$ & 6.9 & 95 \\
\hline & June & $3.5 \pm 0.4$ & $0.09 \pm 0.01$ & 2.7 & 98 \\
\hline & July & $3.9 \pm 0.4$ & $0.16 \pm 0.02$ & 4.1 & 119 \\
\hline & Aug. & $0.8 \pm 0.08$ & $0.03 \pm 0.003$ & 4.5 & 185 \\
\hline & Sept. & $0.7 \pm 0.07$ & $0.05 \pm 0.005$ & 6.7 & 276 \\
\hline & Oct. & $0.4 \pm 0.04$ & $0.03 \pm 0.003$ & 7.5 & 255 \\
\hline & Nov. & $0.2 \pm 0.02$ & $0.01 \pm 0.002$ & 6.0 & 26 \\
\hline & Dec. & $0.1 \pm 0.02$ & $0.01 \pm 0.002$ & 7.0 & 39 \\
\hline \multicolumn{2}{|l|}{ Sum. } & 13 & 0.7 & av.* 53.1 & 1,395 \\
\hline \multirow[t]{12}{*}{1972} & Jan. & $0.2 \pm 0.02$ & $0.01 \pm 0.002$ & 3.5 & 129 \\
\hline & Feb. & $0.3 \pm 0.03$ & $0.01 \pm 0.001$ & 4.4 & 158 \\
\hline & Mar. & $0.4 \pm 0.04$ & $0.02 \pm 0.002$ & 4.1 & 40 \\
\hline & Apr. & $1.3 \pm 0.13$ & $0.10 \pm 0.01$ & 7.6 & 175 \\
\hline & May & $0.1 \pm 0.02$ & $0.07 \pm 0.01$ & 51 & 100 \\
\hline & June & $1.1 \pm 0.1$ & $0.07 \pm 0.01$ & 6.3 & 138 \\
\hline & July & $0.3 \pm 0.03$ & $0.07 \pm 0.01$ & 25 & 359 \\
\hline & Aug. & $0.1 \pm 0.02$ & $0.06 \pm 0.01$ & 46 & 100 \\
\hline & Sept. & $0.1 \pm 0.02$ & $0.02 \pm 0.002$ & 18 & 322 \\
\hline & Oct. & $0.1 \pm 0.02$ & $0.05 \pm 0.005$ & 47 & 39 \\
\hline & Nov. & $0.9 \pm 0.1$ & $0.02 \pm 0.002$ & 2.2 & 21 \\
\hline & Dec. & $0.1 \pm 0.02$ & $0.02 \pm 0.002$ & 17 & 105 \\
\hline \multicolumn{2}{|c|}{ Sum. } & 5 & 0.5 & av.* 10 & 1,701 \\
\hline \multirow[t]{2}{*}{1973} & Jan. & $0.04 \pm 0.004$ & $0.01 \pm 0.002$ & 21 & 135 \\
\hline & Feb. & $0.09 \pm 0.009$ & $0.02 \pm 0.002$ & 25 & 51 \\
\hline \multicolumn{2}{|c|}{ Mar.-Apr. } & $0.20 \pm 0.02$ & $0.02 \pm 0.002$ & 8.4 & 145 \\
\hline \multicolumn{2}{|c|}{ May-Aug. } & $1.6 \pm 0.6$ & $0.02 \pm 0.02$ & 1.4 & 442 \\
\hline \multicolumn{2}{|c|}{ Sept.-Dec. } & $0.6 \pm 0.06$ & $0.02 \pm 0.02$ & 2.6 & 432 \\
\hline \multicolumn{2}{|l|}{ Sum. } & 2.6 & 0.1 & av.* 3.9 & 1,207 \\
\hline
\end{tabular}

\footnotetext{
* The average ratio of 238 to 239 was calculated by the annual sums.
} 


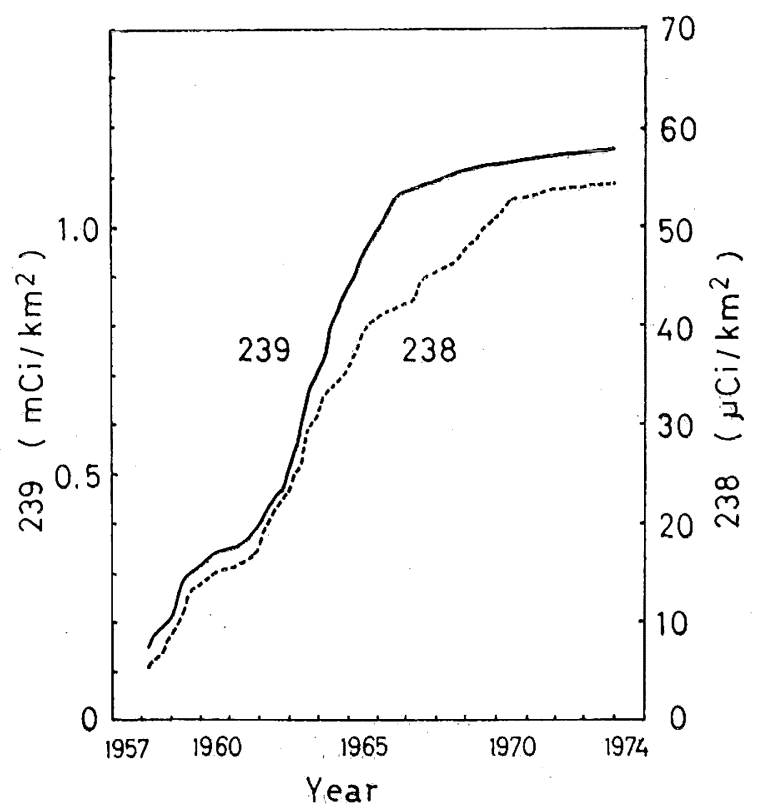

Fig. 1. The cumulative amount of plutonium 239 and 238 deposition in Tokyo.

Table 2. The annual deposition of plutonium 239 and 238 and $238 / 239$ activity ratio.

\begin{tabular}{|c|c|c|c|c|}
\hline Year & $\begin{array}{c}239 \\
\mu \mathrm{Ci} / \mathrm{km}^{2}\end{array}$ & $\begin{array}{c}238 \\
\mu \mathrm{Ci} / \mathrm{km}^{2}\end{array}$ & $\begin{array}{c}238 / 239 \\
(\%)\end{array}$ & $\begin{array}{l}\text { Precipitation } \\
\text { mm }\end{array}$ \\
\hline through Feb. 1958 & 147 & 5.7 & 3.8 & \\
\hline 1958 (Mar.-Dec.) & 56 & 2.9 & 5.1 & 1,654 \\
\hline 1959 & 97 & 5.1 & 5.3 & 1,612 \\
\hline 1960 & 43 & 1.7 & 3.9 & 1,175 \\
\hline 1961 & 37 & 1.6 & 4.4 & 1,232 \\
\hline 1962 & 110 & 6.5 & 5.9 & 1,152 \\
\hline 1963 & 200 & 7.3 & 3.6 & 1,656 \\
\hline 1964 & 185 & 5.3 & 2.9 & 1,132 \\
\hline 1965 & 121 & 4.9 & 4.1 & 1,761 \\
\hline 1966 & 73 & 1. 3 & 1.8 & 1,796 \\
\hline 1967 & 21 & 3.3 & 16.1 & 1,208 \\
\hline 1968 & 25 & 2.5 & 10.0 & 1,644 \\
\hline 1969 & 12 & 3.0 & 25.7 & 1,471 \\
\hline 1970 & 6 & 1.9 & 31.3 & 1,082 \\
\hline 1971 & 13 & 0.7 & 5.1 & 1,395 \\
\hline 1972 & 5 & 0.5 & 10.1 & 1,701 \\
\hline 1973 & 3 & 0.1 & 6.3 & 1,207 \\
\hline Year & 1,162 & 54.3 & av.* 4.7 & $\begin{array}{c}22,881 \\
\text { r. } 1958-1973)\end{array}$ \\
\hline
\end{tabular}

* The average ratio of 238 to 239 was calculated by the total sums of 239 and 238 . 


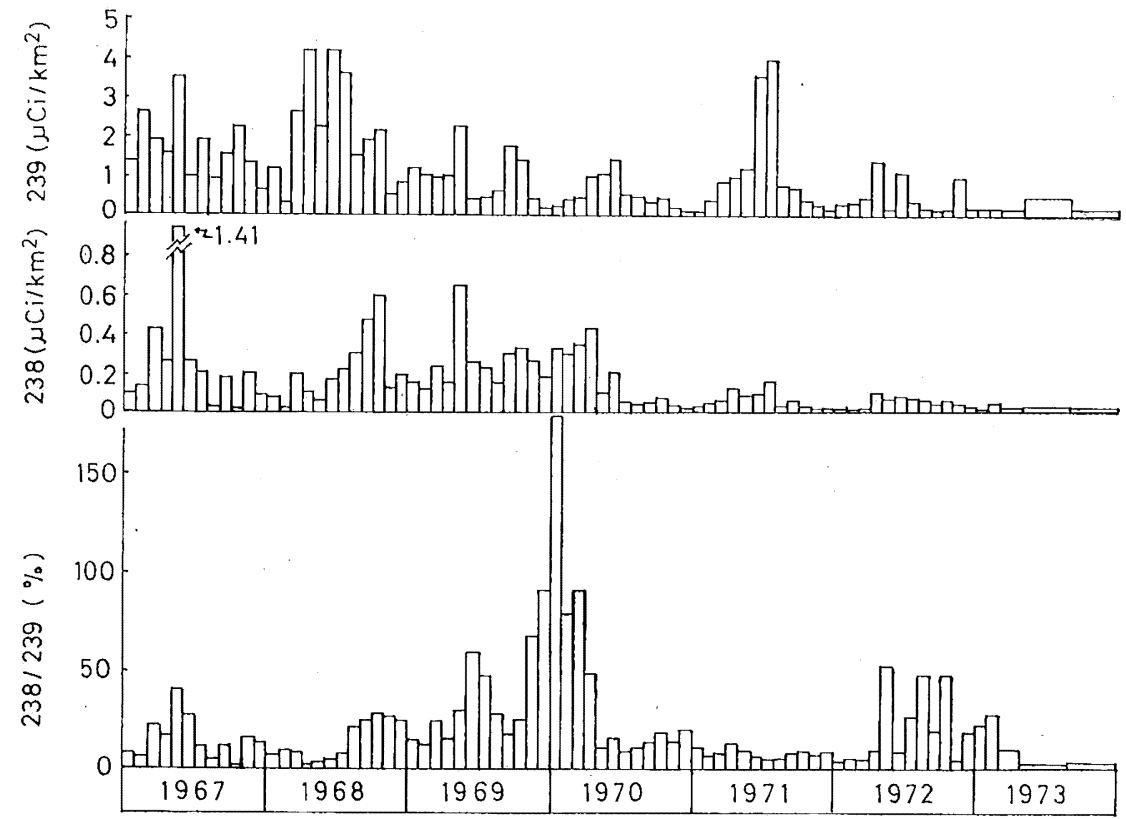

Fig. 2. Monthly deposition of plutonium 239 and 238 and 238 to 239 ratio in Tokyo.

shown any appreciable decrease since 1966 (Miyake and Katsuragi, 1974). This situation is caused by the series of test explosions carried out by the People's Republic of China and France since 1964.

According to MiYake and KATsuragi (1974), most of the radioactive fallout in the northern hemisphere since 1968 comes from the Chinese tests. For example, the portion occupied by the debris of Chinese bombs in the fallout increased from $62 \%$ in 1968 to $98 \%$ in 1973 in Tokyo. The ratio of 239 to Sr-90 during the period of 1968 to 1973 in which the PRC tests prevailed was about $1 \%$, which was considerably lower than the former value of $1.6 \%$ in the tests conducted by the USA and the USSR (Table 3).

Since the year 1967, when the effect of 238 of satellite origin was clearly observed in Tokyo, the fall amounts of 239 and 238 were respectively $85 \mu \mathrm{Ci} / \mathrm{km}^{2}$ and $12 \mu \mathrm{Ci} / \mathrm{km}^{2}$. By using the isotopic ratio of 238 to 239 of $3.9 \%$ of bomb produced plutonium, the estimation on the amount of 238 of the satellite origin was done. The result showed this to be $9 \mu \mathrm{Ci} / \mathrm{km}^{2}$.

In the previous report (MIYAKe and KATSURAGi, 1970, 1974). was given the numerical value of 6.3 , which was the simple ratio of $\mathrm{Sr}-90$ fallout in Tokyo $\left(\mathrm{mCi} / \mathrm{km}^{2}\right)$ to the total amount of deposition of Sr-90 on the northern hemisphere (MCi). By applying the same ratio to the plutonium fallout, the total amounts of deposition in the northern hemisphere of 239 and 238 were calculated to be about $200 \mathrm{kCi}$ and $9 \mathrm{kCi}$ respectively. Of the $9 \mathrm{kCi}$ of $238,2 \mathrm{kCi}$ was of the satellite origin. The results of the above estimations agreed approximately well with those obtained in the soil observations carried out by HARDY et al., (1972). 
Table 3. The activity ratio of annual deposition of 239 to Sr-90.

\begin{tabular}{cccc}
\hline Year & $\begin{array}{c}239 / \mathrm{Sr}-90 \\
(\%)\end{array}$ & Year & $\begin{array}{c}239 / \mathrm{Sr}-90 \\
(\%)\end{array}$ \\
\hline $\begin{array}{c}\text { through the } \\
\text { end of } \\
1958\end{array}$ & 1.6 & & \\
1959 & 1.2 & 1966 & 4.1 \\
1960 & 1.8 & 1967 & 2.6 \\
1961 & 1.8 & 1968 & 2.0 \\
1962 & 1.4 & 1969 & 1.0 \\
1963 & 1.0 & 1970 & 0.4 \\
1964 & 2.2 & 1971 & 1.2 \\
1965 & 2.8 & 1972 & 0.9 \\
& & 1973 & 1.4 \\
\hline
\end{tabular}

* Calculated by the total sums of $\mathrm{Sr}-90$ and 239 .

\section{References}

deBortoli, M. C. and P. Gaglione, 1969: SNAP plutonium-238 fallout at Ispra, Italy. Health Phys., 16, 197-204.

HaRdy, E. P., P. W. KReY and H. L. VolchoK, 1972: Global inventory and distribution of Pu-238 from SNAP-9A. USAEC. HASL-250, 1-32.

Mryake, Y., K. Saruhashi, Y. Katsuragi, T. Kanazawa and S. Tsunogai, 1963: Deposition of Sr-90 and $\mathrm{C}_{\times}-137$ in Tokyo through the end of July 1963. Pap. Met. Geophys., 14, $58-65$.

Miyake, Y., Y. Katsuragi and Y. Sugimura, 1968: Deposition of plutonium in Tokyo through the end of 1966. Pap. Met. Geophys., 19, 267-276.

Mryake, Y. and Y. Sugimura, 1968: Plutonium content in the western North Pacific waters. Pap. Met. Geophys., 19, 481-485.

MiYaki, Y., Y. KatSuragi and Y. Sugrmura, 1970: A study on plutonium fallout. J. Geophys. Res., 75, 2329-2330.

MrYake, Y. and Y. Katsuragi, 1974: Origin of ${ }^{90} \mathrm{Sr}$ fallout in recent years. Tenki, a journal of Meteorological Society of Japan (in Japanese). 21, 639-644.

Telegadas, K., 1969: The seasonal stratospheric distribution of plutonium-238 and strontium-90 March through November 1967. USAEC. HASL-204, I-2-16. 


\section{東京におけるプルトニウムの降下}

三宅泰雄, 葛城幸雄, 杉村行勇

1967 年 1 月から 1973 年末むでの東京に拈けるプルトニウム-239 と238の月間降下量を測定 した。核实験開始以来，1973 年末むでの東京に拈けるプルトニウムの積算降下量は, 239 が 1.2 $\mathrm{mCi} / \mathrm{km}^{2}, 238$ が $55 \mu \mathrm{Ci} / \mathrm{km}^{2}$ になる。原子力電池搭載の人工衛星打上げ失敗によるプルトニウ ム-238 の大気圈放出によって，238/239 比は 1966 年の $1.8 \%$ から 1967 年の $16 \%$ 亿急増し, 1970 年に最大值 $31 \%$ に達した。この比は徐々に減少し 1973 年には $6.3 \%$ になった。

239/Sr-90 比についてみると，中国核実験に由来する放射性降下物が，全降下物中の $98 \%$ を しめる 1968 年から 1973 年の期間に执いて，約 1\%を示し，米国およびり連の核実験に由来す る放射性降下物の比 $1.6 \%$ よりも低い。東京に氺けるプルトニウム降下量から，北半球に特け る全降下量を計算すると, 239 は $200 \mathrm{KCi}, 238$ は $9 \mathrm{KCi}$ となる。 238 の $9 \mathrm{KCi}$ のらち, $2 \mathrm{KCi}$ は 人工衛星起源である。 